DOI: https://doi.org/10.15407/techned2018.05 $: 104$

\title{
ASPECTS OF TECHNOLOGICAL OBJECTS EMULATION AT A FUNCTIONAL TESTING OF ELECTROMECHANICAL SYSTEMS
}

Journal

Publisher

ISSN

Issue

Pages
Tekhnichna elektrodynamika

Institute of Electrodynamics National Academy of Science of Ukraine 1607-7970 (print), 2218-1903 (online)

No 5, 2018 (September/October)

$104-107$

\section{Author}

\section{V.Y. Nozhenko*, , S.S. Starostin**}

Kremenchuk Mykhailo Ostrohradskyi National University, 20, Pershotravneva str., Kremenchuk, 39600, Ukraine, e-mail: sergii.starostin7@gmail.com

* ORCID ID : http://orcid.org/0000-0003-0126-6970

** ORCID ID : http://orcid.org/0000-0002-9137-0562

The approaches to emulation of technological objects at testing of electromechanical systems are considered. Object functions can be implemented based on hardware-in-the loop simulation in different configurations, depending on the test tasks. The emulation is based on discrete-time mathematical models of objects that are usually obtained using continuous prototypes. It is emphasized the obligatory necessity of models testing for stability. The importance of taking into account the inertia of influence on the tested electromechanical system is noted. On the example of a vibration machine, the consideration was given to the dynamic properties of the mechanical load creation in the process of emulation of a technological object. References 9 , figures 4 . 
Key words: electromechanical system, technological object, emulation, analysis.

Received: 05.03.2018

Accepted: 23.03.2018

Published: 16.08.2018

\section{References}

1. Gross H., Hamann J., Wiegärtner G. Electrical feed drives in automation. Erlangen: Publicis Corp., 2001. 336 p.

2. Lentijo S., D'Arco S., Monti A. Comparing the Dynamic Performances of Power Hardware-in-the-Loop Interfaces. IEEE Transactions on Industrial Electronics. 2010. Iss. 57 (4). Pp. 1195-1207.

3. Ren W., Steurer M., Qi L. Evaluating Dynamic Performance of Modern Electric Drives via Power-Hardware-in-the-Loop Simulation. Proc. IEEE International Symposium on Industrial Electronics ISIE2008 June 30 - July 2, 2008. Pp. 2385-2391.

. Cambridge, United Kingdom, 4. Riefenstahl U. Elektrische Antriebssysteme. Wiesbaden: Teubner, 2006. 443 p.

5. Starostin S., Perederiy O. Current Control of a Voltage Source Inverter at the Load Testing of Frequency Converters. Proc. IEEE International Symposium on Industrial Electronics ISIE2008 Pp. 390-392. . Cambridge, United Kingdom, June 30 - July 2, 2008. DOI: https://doi.org/10.1109/ISIE.2008. 4677075

6. Trabelsi S., Schumacher W., Tolksdorf A. Design of a Real-Time Load Simulator Based on an In-Parallel Connected PWM Voltage Source Converter Structure. Proc. $9^{\text {th }}$ European Conference on Power Electronics and Applications EPE2001

. Graz, Austria, August 27 - 29, 2001. 9 p.

7. Izerman R. Digital control systems. Moskva: Mir, 1984. 541 p. (Rus)

8. Nozhenko V.Y., Rodkin D.Y., Havrilets H.O. Characteristics of the vibration moment of a drive motor of an unbalance vibrator. Elektromekhanichni i enerhozberihaiuchi systemy. 2015. No 3 (31). Pp. 39-45. (Ukr)

9. Sergiienko H.S., Starostin S.S. Load testing of power frequency converters based on the 
emulation of electrical machines. Tekhnichna Elektrodynamika. 2014. No 4. Pp. 120 - 122. (Ukr)

$\underline{\text { PDF }}$ 